\title{
Az igazságosság érvényesülése az adóztatásban
}

Az adózás igazságossága - méltányosság - azonosság - optimális adórendszer

\section{Az igazságosság elveinek érvényesülése az adóztatásban}

A 20. század második felében a 70-es évek gazdasági válságának következményeként a polgári államok nagy részében jelentős államháztartási és adóreformlépések történtek. Az Egyesült Államokban 1986-ban adóreformtörvényt fogadtak el, majd George W. Bush 2003-ban újabb jelentős adóreformot hajtott végre. Új-Zélandon 1984-ben, Kanadában 1991-ben fogadtak el adóreformtörvényt, míg a 90-es években Svédországban az évszázad adóreformját hajtották végre. E reformok egyik következménye az volt, hogy előtérbe került az optimális és igazságos közteher-elosztási és -viselési rendszer feltételeinek kidolgozása. Számos szerző törekedett a modern adórendszerekben érvényesülő igazságosság és méltányosság elveinek meghatározására. ${ }^{1} \mathrm{Az}$ e témában megjelent publikációk alapvetően két, egymással gyakran összefonódó megközelítést alkalmaztak. Az egyik megközelítés középpontjában a haszone/vüség, a másikéban a fizetőképesség elve áll.

A fizetöképesség elvét (teljesitmény elvét) a középpontba helyezők az adózás igazságosságát pusztán vagyoni korlátozásként, az adórendszeren belül, a közkiadási, újraelosztási feltételektől függetlenül vizsgálták. Úgy vélték, az adóztatás számos igazságossági elv alapján vizsgálható, de annak középpontjában a formális igazságosságnak, az egyenlő teherelosztásnak kell állnia. Vizsgálódásuk azért vált egydimenzióssá, mert nem vizsgálták az állami ellenszolgáltatást, a társadalmi, szociológiai és gazdasági összefüggéseket. Hiába vetjük össze ugyanis a fogyasztás-, a jövedelem-, vagyonadóztatás éppen hatályos nemzeti szabályait vagy elemezzük az adókulcsokat, az adónemek egymáshoz viszonyított mértékét; ha nem vizsgáljuk az állami ellentételezést, a társadalmi, szociális, gazdasági környezetet az életszínvonal és jövedelmi viszonyokat, akkor objektív adórendszert építhetünk ki, de valójában keveset mondhatunk annak igazságosságáról. Önmagában az adókulcs, az adómérték vagy az adóterhelés nominális mértéke nem árul el sokat sem a belső nemzeti, sem a külső más rendszerekkel történő összevetésben az adórendszerek helyességéről. Azért mert 2012-ben Magyarországon a személyi jövedelemadó egy-

Dr. Szilovics Csaba tanszékvezetö, egyetemi docens, Pécsi Tudományegyetem Állam- és Jogtudományi Kar, Pénzügyi Jogi Tanszék, Pécs, szilo@interszfera.hu.

1 PI. Stiglitz, Joseph E.: A kormányzati szektor gazdaságtana, KJK-Kerszöv, Budapest, 2000; Musgrave, Richard A.-Musgrave, Peggy B.: Az egyenlő teherviselés (az adózási méltányosság) megközelítési módjai, in: Adózás, adórendszerek, adóreformok - Elvek, elméletek, tapasztalatok, szerk. Semjén András, Szociálpolitikai Értesítő, 1993/1-2; FölDEs Gábor: Adójog, Osiris Kiadó, Budapest, 2001. 
kulcsos, a svéd pedig négy kulcsot alkalmaz, önmagában még nem fogalmazhatjuk meg azt, hogy a magyar adórendszer igazságosabb. Nem mondhatjuk azt orwelli mintára, hogy egy kulcs jó, négy kulcs rossz. Az a tény sem árul el önmagában sokat, hogy néhány államban a személyi jövedelmekre 40-50\%-os adókulcsokat, míg más országokban, például Szlovákiában 19\%-os, Oroszországban 13\%-os kulcsot alkalmaznak. Nyilván kevesen fogalmaznák meg ezek alapján, hogy Szlovákia vagy Oroszország társadalmaiban a makroigazság, a társadalmi terhek és szolgáltatások elosztása igazságosabban és méltányosabban történik, mint Dániában vagy Norvégiában, ahol igen magasak a jövedelemadó és az általános forgalmi adó terhei.

Teljesebbnek és mélyebbnek tűnik a - Bentham, Musgrave és Rawls által alkalmazott - haszonelvü (benefit principle) megközelítés. E szerint az adózás igazságosságát vizsgálva az állami redisztribúció egészét, annak minden elemét vizsgálnunk kell, hogy a 20. században kialakult fogalomnak a "társadalmi igazságosságnak” valós tartalmát megállapíthassuk. Ez a megközelítési mód valójában interdiszciplináris módon, sokrétegủen számos terület (jog, gazdaság, szociológia) instrumentumait felhasználva fogalmaz meg állításokat. Musgrave egyik tanulmányában kifejti e metódus gyakorlati alkalmazásának nehézségeit. ${ }^{2}$ Összetett feladat a közjavakból származó egyéni haszon mértékének, valamint az adóalanyok preferenciáinak és ízlésének meghatározása, ebből következően a hasznosság egyénre vonatkozó értékeinek összehasonlítása. A gyakorlatban nem egyszerủ értékelni az egyének számára ténylegesen nyújtott állami szolgáltatásokat, valamint valós képet kapni a vertikális és horizontális adózási egyenlőségröl. Ennek ellenére ezen a gondolaton alapul az adózási elméletben a 20. században megjelenő viszontszolgáltatás elve, miszerint az adóztatási jog alapja az állam által nyújtott szolgáltatásokon nyugszik, és az adó ellenszolgáltatásaként jelenik meg.

\section{Az igazságosság fogalmának gyakorlati értelmezése az adóztatásban}

A nemzeti adórendszerek, az alkalmazott adóztatási technikák, valamint alternatívák közötti választáson alapulva, politikai döntések eredményeként jönnek létre. Az együttműködő vagy paternalista, a kirovó vagy önbevalláson alapuló adóztatás, a sok vagy kevés adókedvezmény, a több vagy egyetlen adókulcs alkalmazása közötti választás is politikai értékrendet, a gazdasági kormányzat igazságosságról vallott nézeteit tükrözheti. Ezt az értékválasztást és a mögötte megbúvó, a társadalom számára küldött üzenetet nehezen érzékelhetővé teszi az adójogi normarendszer technikai, pénzügyi jellegzetessége és az, hogy a mindenkori átalakítás, müködtetés a politika szürőjén át jelenik meg a köztudatban. Fel kell azonban tennünk a kérdést, hogy az adóztatás összetett rendszere, amely állandó fiskális és politikai nyomás alatt áll, alkalmas-e az igazságosság vagy más értékek közvetítésére, érvényesítésére. Az adórendszer müködésének két központi eleme az adóigazgatás szervezete és az adójogi norma. E két elem az adóügyi jogviszony aktív irányító szereplője, amelyekkel kapcsolatban fel kell ismernünk alapvető jellegzetességüket, hogy mü-

2 Musgrave-Musgrave, i. m., 32-33. 
ködési, cél- és eszközrendszerük kívülröl - a politika által - meghatározott. Kétségtelen, hogy az adóigazgatás rendszere és az adójogi norma képes lehet bizonyos pragmatikus értékek, állami attitűd érzékeltetésére, hiszen a politika az adórendszer kialakításakor alternatívák között választhat. Az adóztatásnak éppen e közvetett és kiszolgáltatott jellege miatt az e területen érzékelhető igazságosság sem lehet nagyobb mértékü vagy erőteljesebb, mint az az igazságosság, ami a társadalmi élet más szegmenseiben, így mint a közszolgáltatásokhoz való hozzájutásban vagy a közpénzek felhasználásában, újraelosztásában egyébként érvényesül.

Az adózási igazságosság egyik feltétele tehát a jól érzékelhető társadalmi értékrendszer lenne, amelyben világos igazságossági feltételeket találunk. Ezért lenne fontos az, amit Ádám Antal - az értéktan legismertebb magyar kutatója - alkotmányjogi megközelítésböl „közös értékminimumnak”, a társadalom nélkülözhetetlen kincsének nevez. ${ }^{3}$

Mind adójogi, mind jogelméleti nézőpontból egyetérthetünk azzal, hogy szükség lenne a jogi alapértékek kimunkált rendszerére. „A jogi alapértékeknek az a megkülönböztető természete, hogy meghatározzák az egyéb jogi értékek kereteit és föbb tartami összetevőit is, ezáltal hatást gyakorolnak a nem jogi - a gazdasági, a kulturális, a müvészeti stb. - értékekre is." ${ }^{4}$

Az alapértékek kaleidoszkópját gyakran átrendező politikai vagy fiskális szükség a közép-kelet-európai régióban nem képes az igazságosság stabil rendszerét kiépíteni, és így az adóztatás igazságossága sem képes érvényesülni. Meg kell jegyeznem, hogy az adózás igazságossága nem választható el a társadalmi igazságosság általános érvényesülésétől, de meghatározható néhány technikai, formai jellegzetessége. Látnunk kell: ahogy nem létezhet egymástól elkülönülten és párhuzamosan érvényesülő, de lényegesen eltérő erkölcs és adóerkölcs, úgy az igazságosság és az adóztatás igazságossága is egymásra utalt, egymást alakító fogalmak. Az adóztatás igazságossága a közösségben érzékelhető igazságosság részeként értelmezhető. Néhány kisebb eltérés, jellegzetesség ellenére határait a jogi alapértékek, gyakorlati érvényesülését az általában müködő társadalmi gyakorlat határozza meg, és benne a közösség értékfelfogása tükröződik. Megállapíthatjuk, hogy az adóztatási igazságosság mindig a társadalmi feltételektől meghatározottan müködik, a folyamatos államháztartási reformszándékoknak kiszolgáltatottan. Gondoljuk végig, hogy a vizsgált fogalom érvényesülésére milyen hatással van a közpénzek kezelésének gyakorlata és a folyamatosan változó jogszabályi környezet.

Az elmúlt húsz év magyar gyakorlatát vizsgálva és feltételezve azt, hogy a döntési helyzetbe kerülő politikusok kizárólagos célja a közérdek, a közjó szolgálata volt, megfogalmazható néhány észrevétel. Azt láthatjuk például a nyugdíjrendszer átalakítását vizsgálva, hogy a kormányok olykor egymástól homlokegyenest különböző módon kívánták ugyanazt a célt megvalósítani, és az igazságosság ürügyén hol az önkéntes, hol a kötelezö öngondoskodás, hol az állami kizárólagosság kereteit határozták meg. Azt, hogy az egyén számára melyik megoldás lett volna igazságosabb, nem tudjuk meghatározni, hiszen az egyének élethelyzetüktől függően tarthatják

\footnotetext{
3 ÁdÁm Antal: Alkotmányi értékek és alkotmánybíráskodás., Osiris, Budapest, 1998, 36.

4 ÁdÁm Antal: A magyar Alkotmányból hiányzó alapértékekről., Közjogi Szemle, 2009/1, 1.
} 
számukra helyesnek az öngondoskodást vagy a kizárólagos állami támogatást, életpályájuktól, felhalmozott jövedelmüktöl, egyéni szolidaritásuktól függően. De nemcsak az egyének érdekeit nem tudjuk meghatározni, hanem makroszinten ezen érdekek kumulálására sem vállalkozhatunk. Hiányzik a magyar közpénzügyi rendszerböl a kormányzati ciklusokon átívelő, a közérdekből levezethető stratégiai célok meghatározása és tiszteletben tartása. Ezek hiányában az egymást követő kormányzati lépések sem lehetnek helyes és igazságos lépések, amikor sem a célt, sem az oda vezető utat, de még a szükséges részeszközöket sem ismerjük, és nem jutottunk velük kapcsolatban társadalmi konszenzusra.

Alapvetően rombolja le az igazságosság érvényesülését az a helyzet, amelyet a szabályozás állandó változása okoz. Negatív módon hat az, hogy ma szabadon megtehetjük azt, ami tegnap még tilos volt, vagy amit ma kötelezően teszünk, azt az állam holnap lehet, már nem támogatja, sőt talán tiltja is. E helyzettel kapcsolatban így fogalmaz Walzer: „Kimondhatjuk, hogy az igazságos társadalom jobb a zsarnokságnál, de azt nem tudjuk megmondani, hogy melyik igazságos társadalom jobb a másik igazságos társadalomnál. Ehhez standardként szükség lenne a jó abszolút eszméjére, de a filozófia kizárja egy ilyen eszme lehetőségét." ${ }^{5}$

A létező jogi rendszerek ismeretében, e gondolattal egyetértve megfogalmazható, hogy az igazságos adórendszer standardjai még soha semmilyen államban nem jöttek létre. Ettől függetlenül még lehet helyes és értékes törekvés e feltételek keresése. Nem mondhatjuk azt, hogy mert nehezen leírhatók az optimális közpénzügyi rendszer feltételei, akkor törődjünk bele a rossz és igazságtalan müködésbe. Valójában a nemzeti megoldások között minőségük és igazságosságuk tekintetében vannak fokozatok, tehát a jobb és rosszabb megoldások elkülöníthetők. A nehézséget az jelenti, hogy a pénzügyi és adójogban nincsenek a világon általánosan elismert, kiforrott és egységesen alkalmazott alapelvek, miként a polgári, a büntető- és az alkotmányjog néhány alapeszméjében. Az emberölés tilalma, az adásvétel formalizált aktusa, a polgári jogegyenlőség, a teljes és általános választójog a fejlett államok közösségében azonos vagy hasonló módon jelenik meg. llyen egységes fogalom- és intézményrendszert a pénzügyi jog területén csak parciális elemekben (például az Európai Unión belül néhány közvetett adónál, vámoknál) találhatunk. Az adójog területén pozitív példaként említhető a visszaható hatályú adóztatás és a konfiskatórius adóztatás legtöbb tagállamban érvényesülő tilalma. Ugyanakkor az Európai Unió hatályos jogában a közvetlen adóknál (társasági és személyi jövedelemadók) óriási különbségek figyelhetők meg a mértékek, a kedvezmények, az adóigazgatás gyakorlatának tekintetében. Így tehát be kell látnunk, hogy az igazságosság e rendszerben történő elemzése alapvetően meghatározott az adott állam, gazdaságpolitikai cél- és értékpreferencia rendszerében.

Ha azonban az adórendszert körülölelö társadalmi feltételekre mint a jogalkotás elvi korlátaira tekintünk, akkor az igazságosság fogalmát kiszolgáltatjuk az éppen aktuális gazdaságpolitika szándékainak. İgy azonban tudomásul kell vennünk, hogy nem az optimális, hanem az éppen lehetséges legjobb feltételeket kereshetjük. Eb-

5 WALzer, Michael: Spheres of Justice, Blackwell, Oxford, 1983. 318., idézi Bujalos István: Igazságosság Amerikában, Esély, 2005/3, 28. 
ben a megközelítésben tehát, az adózás igazságossága úgy határozható meg, mint az adott társadalom kulturális értékrendszeréből következő adottság. Ahogy Walzer fogalmaz: „A politikai közösség alakítja ki az elosztási szférák komplex egyenlőségét.”6 Ez azt jelenti, hogy a kérdést csak az adott társadalmi helyzetben érdemes vizsgálni, és nem egy „elméleti állam” viszonyai között. Az adózás igazságossága tehát társadalmi és kulturális termék, amely a létező viszonyok eredményeként jött létre, s amely csak a társadalomban aktuálisan érvényesülő egyéb jogok és lehetőségek tükrében elemezhető. Eszerint ha elfogadja a társadalom, hogy az adóztatás határait a kormány autonóm módon határozhatja meg, az igazságosság fogalma is csak e kiszolgáltatott relációban érvényesülhet. Éppen ezért mondja számos közgazdasági gondolkodó - így például Musgrave és Jasay ${ }^{7}$ - a 19-20. században, hogy szemben más jogterületekkel, az adónorma jellegzetessége éppen az, hogy az általános jogi alapértékek helyett gazdasági, fiskális érdekek mentén jön létre, így szükségtelen annak belső értéktartalmát vizsgálni. Ismerve és elismerve ezeket az érveket, úgy vélem, a tökéletesebb adórendszer, adóztatás feltételeinek meghatározását nem mellőzhetjük.

A fenti gondolatmenet után meghatároznám az adóztatási igazságosság jellegzetességeinek megfelelően azokat a feltételeket, elvárásokat, amelyek befolyásolhatják az igazságosság érvényesülését. Ezek a feltételek egymásba fonódnak és együttesen hatnak. Az első feltétel az optimális adórendszer keresésének az igénye, ideértve az egyenlő és méltányos adóteher-elosztást is. A másik feltétel a makro-igazságosság érzékelése, beleértve a közszolgáltatásokhoz való hozzájutás esélyeit is.

\subsection{Az optimális adórendszer feltételei}

Gondolatmenetem kiindulási pontja az, hogy az államnak kötelessége az államháztartási alrendszerek költségvetésének meghatározásakor a szükséges müködési költségek minimumához ragaszkodni. A jövedelemtulajdonosoktól csupán annyit jogosult elvonni, ami ehhez a minimumhoz feltétlenül szükséges. A pazarlás nem csupán a kiadási oldal teljesítésekor, az állami müködés megvalósulásakor, hanem már a bevételi oldal meghatározásakor jelentkezhet. Ez a megközelítés nem csupán az állam hatékony müködésére mint alapkötelezettségre hívja fel a figyelmet, hanem arra is, hogy a túl- vagy aluladóztatás és az adózói csoportok közötti egyensúly kialakítása is lényeges. Az állami „túl elosztás”, a közpénzek pazarló felhasználása vagy a korrupció jelenségei torzítják az adórendszer belső összefüggéseit és gyakran azt eredményezik, hogy a kormányok a hiány kezelése érdekében a legvédtelenebb, közpénzügyi elvonással legkönnyebben elérhető társadalmi csoportokra helyezik az adóztatás fő terheit. A nem optimális adórendszer ugyanakkor torzítja a nemzeti piac, a nemzetgazdaság versenyképességét, forrásokat von el a gazdasági szereplőktől, és így közvetett módon csökkenti a gazdasági növekedés esélyeit. Jackson szerint: „A gazdasági tankönyvek jellemzően úgy mutatják be a problémát, hogy egy adott időpontban a gazdasági boldogulás maximalizálása szempontjából jelentéktelen kér-

6 Walzer: i. m., 318. idézi Bujalos: i. m., 28.

7 Musgrave-Musgrave: i. m.; De Jasay, Anthony: Az állam, Osiris, 2002. 
dés, vajon az újraelosztás révén elért jövedelemegyenlőség optimális-e. A szegény nagyobb jövedelme többet »használ«, mint amennyit a gazdag elmaradt »haszna« árt. A középponti probléma mindazonáltal az igazságosság és a gazdasági növekedés összefüggésében vetődik fel."8

Az optimális adórendszer keresése valójában a leghatékonyabb „rendszer” keresését is jelenti, ami azonban nem jelentheti azt, hogy az adóztatás fő célja a minél több adóbevétel kipréselése lenne. Figyelembe kell vennünk Arthur Okun megállapítását: „A hatékonyságra törekvés szükségképpen egyenlőtlenségeket teremt, ezért a társadalom az egyenlőség és hatékonyság kompromisszumával szembesül."9 A hatékonyság közgazdasági gyökerü fogalom, amelyben a ráfordítások és az eredmény közti összefüggéseket vizsgáljuk az előállított értéktöbbletet minősítve. Az adórendszerben a bevételek puszta maximalizálása nem lehet végcél. Értelmes feladat kiszámolni és elemezni az adóalanyok elméleti teherviselőképességét, de az csak számos más tényező együttes hatásaként vizsgálható. Ilyen lehet a jog hatékonysága, a feketegazdaság mértéke, az adóigazgatás munkájának színvonala vagy a szociális elosztórendszer. Vonzó lehet a jogalkotók számára, hogy a kiadásokhoz szabják a tervezett bevételeket. Ahogy Szemere Bertalan fogalmazott a magyar országgyülésben 1849 májusában az adóreformról folytatott vitában, ahol a progresszív és demokratikus elvek hiányát vetették a szemére, és ő válaszában az adórendszerre vonatkozóan azt mondta: „Nem jobbat akarok, hanem adót akarok mindenáron.”10 Ezekkel a gondolatokkal teljesen ellentétesen fogalmaz a hatékonysággal kapcsolatban John Rawls: „Az igazságosság alapján rendelkezik minden egyes személy azzal a sérthetetlenséggel, amelynél még a társadalom egészének jóléte se lehet fontosabb. Ezért nem teszi lehetővé az igazságosság egyesek szabadságának feláldozását azon az alapon, hogy ezáltal több jót kapnak mások. Ezért nem engedi meg, hogy a kevesekre kirótt szenvedésnél fontosabb legyen a sokaknak nyújtható legnagyobb előny."11

Az igazságos adóztatás alapkérdése az optimális adóterhelés kialakítása. A jogalkotók többsége legalábbis formálisan, a modern adórendszerek kialakulása óta ezt a célt tűzte maga elé. Ennek a gyakorlati megvalósítása talán sohasem sikerült. Gyakran megfigyelhető, hogy a kormányzatok a közbevételi rendszernek csak a bevételi forrás jellegét vették figyelembe, és nem az adófizetők lehetőségeihez, hanem a kormányzati igényekhez igazították az adóbevételeket. Ez kétségkívül lehet adóztatási szempont, de nem válhat kizárólagossá és nem szüntetheti meg más közcélok érvényesülését. Az optimális adórendszer kialakítása folyamatos egyensúlykeresésként határozható meg, amelynek középpontjában az indokolt és felismert közérdek áll. Ezek meghatározása azonban nehéz feladat. Ezért tűnik elfogadhatónak az a kormányzati megoldás, hogy a legkisebb vagyoni korlátozás mellett a legszüksége-

8 JACKSON, Andrew: Miért nem kell választanunk a társadalmi igazságosság és a gazdasági növekedés között, Esély, 2007/2, 5.

9 Okun, Arthur M.: Equality and Efficiency: The Big Trade-off, Brookings Institution, Washington, $1975,55$.

10 Berend T. Iván-SzuhAY Miklós: A tőkés gazdaság története Magyarországon 1848-1944, Kossuth Könyvkiadó, Budapest, 1975, 23.

11 Rawls John: Méltányosságként felfogott igazságosság, in: Modern politikai filozófia, szerk. Huoranszki Ferenc, Osiris Kiadó, Láthatatlan Kollégium, Budapest, 1998, 21-22. 
sebb közcélok érdekében határozzák meg az adókat, amelyeket az elfogadható legnagyobb adóigazgatási szigorral ellenőriznek.

Amoros és Vasco, a spanyol adóhatóság vezetői azonban rámutattak arra, hogy az optimális adórendszer kialakítása valójában az adózási célok egy csoportjának összhangját jelentené, de ezek sem együttesen, sem azonos mértékben nem tudnak megvalósulni. „Más szavakkal, ellentétek vannak a modern adóstruktúra által megvalósítandó különböző célok között, és így az elérhető megoldás csak a második legjobb lehet."12 A célok között hierarchiát kell az adópolitikának felállítania, tehát az optimális adórendszer ideája illúzió, és a gyakorlatban csak kompromisszummal valósulhat meg.

Az optimális adórendszer meghatározásában jelentős segítséget nyújthatna egy nemzetközi adózási standard kidolgozása. Már a század elején megindultak azok a kutatások, amelyek az adóztatást, a lehetséges és optimális adóterhelést és adóstruktúrát vizsgálták. Az optimális adórendszer keresése az igazságos adóztatás minimumaként és a kormányzatok kötelező feladataként is felfogható. Az egészséges adórendszer meghatározásának első lépéseként 1915-ben Watkins felvetette a "Capacity factor” hatékonysági index alkalmazásának szükségességét. ${ }^{13}$ Ebben azt javasolta, hogy az aktuális adóeredményt - bevételt - vessék össze a társadalomban elméletileg lehetséges legjobb gyakorlatból származó eredménnyel. Wesley Mitchel 1937-ben az USA-ban, Ackermann 1923-26-ban Svédországban ez alapján vizsgálták az adórendszer teljesítményét. Ők és más szakértők Bird, Caragata, illetve hazánkban Földes Gábor és László Csaba összefüggést állapítottak meg a GDP redisztribúciójának szintje és az adórendszer hatékonysága között. A redisztribúció szintje azonban azt nem árulja el, hogy a különböző adófajták hogyan és milyen arányban teljesülnek, és hogy alakul az adózók és foglalkozási rétegek vertikális és horizontális adóteher-elosztása.

\subsection{Egyenlő adóterhelés problémája és annak érzékelése}

Földes Gábor e fogalmat vizsgálva meghatározta: az adózás igazságossága az adóterhek igazságos terítését jelenti a társadalom tagjai, szervezetei között, és ez nem csupán alkotmányossági, hanem gazdasági és etikai kérdés is. Az elosztási elveket két fö csoportra osztotta, az osztó- és a kiigazító igazságosságra. Ugyanakkor megfogalmazta, hogy az elosztás igazságossági elveit a gyakorlatban szinte lehetetlen következetesen alkalmazni. Az igazságos adóztatást a fajlagosan arányos teherviselés valósíthatja meg. ${ }^{14}$ Takács György idézi lbn Chaldunt, a 14. században élt arab tudóst, aki szerint: „,zzámításba kell venni az adófizetők teherbíró képességét”. ${ }^{15}$ Az 1900-ban kiadott Közgazdasági Lexikon egy cikkének szerzője szerint az

12 Amoros-Vasco: Tax Evasion in Spain, Cahiers de droit, IBFD, Amsterdam, 1992., 37-43.

13 Caragata, Patrick J.: The Economic and Compliance Conseqvences of Taxation, Kluwer Academic Publishers, Boston, 1998, 13.

14 FÖLDES: i. m., 20-22.

15 TAKÁCs György: A pénzügyi büntetőjog kifejlődése, in: Közgazdasági Lexikon, Pallas, 1900, 367. 
igazságos adórendszer egyik alapfeltétele az igazságos anyagi jövedéki büntetőjog. A szerző itt közvetetten szintén az adóterhelés igazságos elosztásának szerepére hívja fel a figyelmet. „Minél helyesebben van összeállítva egy adórendszer, minél kevesebb olyan követelménnyel állnak elő az egyes adótörvények, amelyeknek az egyes adózók létérdekük kockáztatása nélkül megfelelni nem képesek, annál szükségesebb, de egyszersmind annál könnyebben keresztülvihető egy szigorú büntetőjog, amely az állam iránti kötelességeit híven teljesítő adózókat hathatósan védi ezekkel szemben, akikben megvan a hajlam arra, hogy kötelességük alól kibújjanak."16

Yankelovich, Shelly és White kutatásai azt mutatták - fogalmaz Spicer -, hogy az amerikai adófizetők körében igen elterjedt az a nézet, hogy az emberek azért csalnak adót, mert úgy gondolják, az adórendszer nem méltányos, azaz igazságtalan. ${ }^{17} \mathrm{Azt}$ a tapasztalást, hogy az adócsalást támogató hozzáállás korrelációban van azzal, hogy mennyire érzékelik az adózást méltánytalannak, több kutatás - Spicer, Becker (1980), Clark és Matoney (1984) - is megerősíti. Spicer azonban rámutatott arra is, hogy az igazságtalanság érzékelésének mint jogkövetést befolyásoló tényezőnek a hatása erőteljesen függött a motiváló tényezők erejétől. Az adórendszer igazságtalansága elsősorban azokat befolyásolta, akiknek kevesebb félnivalója volt a sikertelen adócsalással együtt járó társadalmi megbélyegzettségtől és a jogi szankcióktól. ${ }^{18}$ A magyar származású Anthony de Jasay „Az állam” címú munkájában arról ír, hogy „valamely csoportról mindig elmondható, hogy mások rovására jártak jól”. ${ }^{19}$ Valószínúsíthetően ezek nem az adójukat ténylegesen megfizető jómódúak. A közpénzek előállításának folyamata (tehát a társadalmi újraelosztás) megzavarja már az adózás előtt a társadalmi igazságosságot, „így tehát az állam sokak pártjára állhat a kevesekkel szemben, és a szegények pártjára a gazdagokkal szemben azon az alapon, hogy ezzel kiegyensúlyozza az összboldogságot vagy a társadalmi igazságosságot”. ${ }^{20}$ Ez a felismerés a több adót fizető személyeket és társaságokat semmiképpen sem serkenti jogkövetésre, hacsak nem tételezzük fel, hogy saját anyagi és abból származó egyéb előnyeiket hátrébb sorolják a társadalom egészének boldogságával szemben.

Az adóztatással kapcsolatos igazságosság érzékelésének az egyik problémája, hogy az egyénnek szembesülnie kell azzal, hogy az „adófizetés ellenében nem szerezhet közvetlen jogosultságot valamilyen ellenszolgáltatásra. Nem tarthat igényt többletjogokra - pl. több költségvetési támogatásra vagy egyes privilégiumokra - azért, mert nagyobb összegű adóval vagy más befizetéssel járult hozzá a bevételekhez, mint más személyek."21 Az adófizetésért kapott állami ellenszolgáltatás közvetett és időben eltolódik: a polgár fizetési kötelezettségét azonnal és teljes mértékben érzékeli, míg a közjavak csak később, olykor egyáltalán nem jutnak el hozzá. Árnyalják ezt a képet Cowell (1990), Spicer, valamint Becker (1990) kutatásai. Ezek azt mutatják, hogy az egyén képes nagyobb adózási összefüggések értékelésére, és adózási

\footnotetext{
Teleszky János: Jövedéki büntetőjog, in: Közgazdasági Lexikon, Pallas, 1900, 247.

SpICER, Michael W.: The Problem of Tax Evasion, National Tax Journal, vol. XXXIX. 1986, 16.

SPICER: i. m., 17.

19 De JASAY: i. m., 146

20 DE JASAY: i. m., 147

21 FöldEs Gábor: Pénzügyi alkotmányosság, Társadalmi Szemle, 1996/1. 65.
} 
döntéseiben az egyéni megítélés és igazságtalanság érzékelése kibővül az egész adórendszer igazságosságáról kialakult véleménnyel, és a mások becsületességéröl, valamint a kormány tevékenységéről alkotott képpel - összegzi e kutatások tapasztalatait Triest és Sheffrin. ${ }^{22} \mathrm{E}$ vizsgálódások eredményeit analizálva néhány kutató - Kaplan és Reckers (1985), Song és Yarbrough (1978) - kimutatta, hogy a jogkövetésben az adófizetési morál fontosabb lehet, mint az igazságtalanságok érzékelése, tehát a társadalmi morál helyzete közvetlenül befolyásolja az egyéni erkölcsöt.

Talán még ennél is fontosabb azonban az, amit Brickman "makroigazságnak” nevezett, és a társadalmi elosztás tisztességeként határozott meg. „Az adófizetők - írja - különböző kritériumok alapján értékelhetik, hogy a társadalmi elosztás tisztességese."23 Ezzel kapcsolatban a társadalmi rétegek azonos helyzetének létrehozását tekinti célnak. ${ }^{24} \mathrm{~A}$ német Kurt Miehler szerint: az adótörvényeket az igazságosság és jogosság elvei alapján kell meghatározni, és az adózást nem az államapparátus igényeihez, hanem az állampolgárok fizetési kapacitásához kell igazítani. Úgy véli, hogy „a polgár akkor lesz hajlandó teljesíteni a rá törvény által kirótt kötelezettséget, ha meg van arról győződve, hogy az ő közösségi hozzájárulása egy igazságos öszszegben fejeződik ki”. Az adózó, aki lényéből fakadóan önző, úgy tekinti az adófizetési folyamathoz való saját hozzájárulását, mint amiböl szükségképpen nem ő, hanem valaki más fog hasznot húzni. ${ }^{25}$

Az adózók tehát nemcsak az adózási csoportok szerepét és helyzetét ismerik fel, hanem a kormányét is. Caragata szerint: „Felismerték, hogy a kormányok a társadalom rétegeire - csoportjaira inkább különböző adókötelezettségeket és adószabályokat állapítanak meg, mintsem hogy az adófizetőket egységes osztálynak tekintsék." 26 Az adózói csoportok vertikális és horizontális egyenlőségének igénye azt a követelményt fogalmazza meg, hogy az azonos teljesítőképességgel - adózási képességgel - rendelkezők azonos összegủ adót fizessenek. A kormányok azonban gyakran éreznek késztetést bizonyos foglalkozási, vagy regionális, vagy egyéb kedvezmények biztosítására, ami sok szempontból sértheti az adózás igazságosságát. A kormányok indítéka lehet a lustaság, az adórendszer csődjének beismerése, de lehet aktuálpolitikai indíttatású is. Kétségtelen, hogy ez a jelenség általános. A görög Mavraganis és Agapitos szerzőpáros arról számolt be, hogy a görög adózók igazságérzetét folyamatosan aláássák az olyan növekvő számú mentességekkel, amelyeket az állam az egyes társadalmi csoportoknak felajánl. „A méltányosság elvének ilyen aláásása az adócsalás igazolásának alapjául szolgált. Az 1995-ben elfogadott költségvetéshez kapcsolódó adómentességek 1000 milliárd drachmás bevételkiesést jelentettek. Ez

22 Sheffrin Steven, N.-Triest, Robert K.: Can Brute Deterrence Backfire? Perceptions and Attitudes in Taxpayer Compliance, in: Why People Pay Taxes, Slemrod, Joel (ed.), The University of Michigan Press, 1992, 205-203.

${ }^{23}$ Brickmant idézve Carroll, John S.: How Taxpayers Think about their taxes: Frames and Values. in: Why People Pay Taxes, Slemrod, Joel (ed.), The University of Michigan Press, 1992, $43-61$.

24 Uo.

25 Mienler Kurt: Individual Behavior and Tax Conscionusness, in: Technical Paper and Reports of the 18 th. General Assembly of the Inter-American Center of Tax Administrations Columbia (21-25. May/Amsterdam), IBFD, 1984, 135-137.

26 Caragata: i. m., 3. 
azt jelenti, hogy bizonyos társadalmi csoportok kevesebb adót fizetnek, mint más azonos jövedelemszintűek pusztán azért, mivel nekik sikerült adózási privilégiumokat szerezniük az államtól." A kieső adóbevételeket azonban nyilvánvalóan más adózók fizetik meg. Így érthető, hogy ebben az igazságtalan helyzetben azok, akik nem tudják az adókedvezményt igénybe venni, az adócsalást választják akkor is, ha korábban becsületesek voltak. Az adócsalásra úgy tekintenek, mint a méltányosság helyreállításának eszközére. ${ }^{27}$

Hasonló folyamatot ábrázol M. M. Guevara a Fülöp-szigeteken. A jövedelemadórendszer igazságtalan - mutatja be -, mert a vállalkozások és az alkalmazottak adózási helyzete gyökeresen különbözik, és nagy az adóterhelésük közötti eltérés. „Még az alkalmazottak átlagos adóterhelése 10,6\%-os, addig a vállalkozóké mindössze 1,4\%-os" - idézi a pontos adatokat. ${ }^{28}$

Hasonló adóztatási különbségeket figyelhetünk meg a magyar rendszerben is, pl. a közalkalmazottak - köztisztviselők - és az átalányadózó egyéni vállalkozók, az egyszerűsített vállalkozói adót fizetők jelentős adóteher-különbségeiben vagy a költségleírás, adójóváírás lehetőségeiben. Megfogalmazható, hogy az adórendszerekben alkalmazott kedvezmények alapvetően veszélyeztetik az igazságosság érvényesülését, hiszen átstrukturálják az adóterheket. A jogalkotóknál folyamatos nyomás jelentkezik, hogy az igazságosság különböző érvényesülési módjai közül válasszanak. Dönteniük kell az érdem (megadni mindenkinek, amit megérdemel), a hasznosság (megadni azt, ami a közösség számára a leghasznosabb), a szükségletek (megadni mindenkinek, amit igényel), a jogosultságok (megadni, amihez joga van) és más kiigazító, családi és egyéb értékszempontok között. Ezek együttes és kiszámítható alkalmazása lehetetlen, ezért a kormányzatok számára vonzó alternatíva lehet az adókedvezmények, tehát az adórendszerek szubjektív elemeinek a csökkentése. A társadalom jelentős része azonban igényt tart a személyes feltételeihez kapcsolódó kedvezményekre.

\section{A méltányosság és az igazságosság fogalmi kapcsolata}

Vizsgálódásunk következő lépésében a gyakran szinonimaként használt méltányosság és igazságosság fogalmi kapcsolatait tekintem át.

Abban az esetben, ha az igazság azon jelentéstartamából indulunk ki, miszerint az igazság a valóságnak a megismerési pontosságát jelenti, annak egyszerű tükröződése, akkor vizsgálódásunk szempontjából nézve e két fogalom nem feltétlenül egyezik meg, mert ez az értelmezés nélkülözi az erkölcsi tartalmat. A méltányosság, mint értékközpontú fogalom, ebben az esetben elválhat az igazságosságtól. Könnyen feltehető ugyanis olyan szabályok vagy jogi gyakorlat létezése, érvényesülése, amelyekkel szemben az egyetlen követelmény, hogy a szabályokat az azok alá sorolha-

27 Agapitos George-Mavraganis, George: Tax Evasion: The Case of Greece, Bulletin of IBFD XII., 1995, 569576.

28 Guevara, Milwida M.: The Underground Economy in Philippines, Paper of IBFD, 1992, 46-47. 
tó valamennyi esetben pártatlanul alkalmazzák. ${ }^{29}$ Ezt nevezhetjük a jogalkalmazás formális igazságosságának vagy az eljárási igazságosságnak. „A formális igazságosság azt jelenti, hogy ugyanazokra az esetekre ugyanaz a szabály vonatkozik, vagy az azonos osztályokba tartozó emberekkel azonos módon kell bánni. A formális igazságosság az egyenlőséget erősíti, hiszen azt követeli, hogy az azonos csoportokba (ti. az azonos kategóriákba, osztályokba) tartozókkal ugyanolyan módon bánjanak; ámbár nem mond semmit arról, hogy miféle egyenlőséget pártol”30 - írja Takács Péter. Elképzelhető e megközelítés szerint, hogy valamely jogi helyzet nem sért jogi normát, de ugyanakkor valaki számára méltánytalan. Ilyen lehet egy adott országban kialakult bérrendszer, vagy az egyébként jogszerüen járó pótlékok ki nem fizetése, vagy az orvosi túlóra kezelése, vagy az állami támogatások elosztása. A szükös költségvetési korlátokat figyelembe véve eljuthatunk annak a megfogalmazásáig, hogy járni jár, de nem jut. A magyar Alkotmánybíróság deklarálta ezt az elvet, amikor a szociális biztonsághoz való jog tartalmának meghatározásával kimondta: „Az állam ezen kötelezettségének azáltal tesz eleget, hogy megszervezte és müködteti a társadalombiztosítás és a szociális ellátórendszer egyéb intézményeit. Az állami kötelezettség csak a megélhetéshez szükséges minimális szint vonatkozásában áll fenn, az egyéb szociális jellegủ juttatások pedig az állam teherbíró képességétöl függenek." ${ }^{11}$ Részben e jogi nézőpontból következhet az, hogy lehet valamely társadalmi helyzet, jogi döntés formálisan igazságos, jogszabálynak megfelelő, de ettől még nem feltétlenül méltányos. Ez a helyzet az erkölcsi és a jogi normák közötti tartalmi különbségböl is fakadhat.

Ha azonban az igazság fogalmát mint egy közösségben kialakult erkölcsi, jogi eszményt határozzuk meg, akkor az ezzel egybeeső valamely érték, teljesítmény, érdem nyilvánvalóan méltányolható, tehát itt egybeesik e két fogalom. John Rawls Méltányosságként felfogott igazságosság címú munkájában úgy fogalmaz, hogy az egyéni akarattal és célokkal rendelkező egyéneknek akkor méltányos a helyzete, ha senki sem kerül előnybe vagy hátrányba. Mindenki egyenlő helyzetben van a tekintetben, hogy nem tudja mások kárára érvényesíteni akaratát. Tehát a méltányosság itt azt jelenti, hogy igazságos alku eredményeként jött létre az egyensúlyi-egyenlő helyzet. ${ }^{32}$ Ezt a helyzetet nevezi „méltányosságként felfogott igazságnak”. Tehát az igazságosság elveit a méltányosság kiindulási pontjaként fogta fel. Bár a fenti gondolatmenetből Rawls szerint sem következik, hogy a méltányosság és az igazságosság fogalma azonos.

29 Lásd bővebben FenYVESI Csaba-HeRKe Csongor-TREMmel Flórián: Új magyar büntetőeljárás, Dialóg Campus Kiadó, Budapest-Pécs 2004, 35.

30 TAKÁcs Péter: Jog és igazságosság. Jogbölcseleti elöadások, Miskolc, 1998, 166-167.

31 42/2007. (VI. 20.) AB-határozat, 3.

32 RaWls: i. m., 28. 


\section{Az azonosság vizsgálata}

Az azonosság vizsgálatánál kiindulási pontként Arisztotelész gondolatát alkalmazzuk: ,...az igazság megköveteli az azonos mérce alkalmazását és a különbségtételt. El kell fogadnunk, hogy a jó tanárnak jogában áll a jó feleletet jóra, a rossz feleletet pedig rossz jegyre minősíteni. Ez azt jelenti, hogy az értékek meghatározásának szempontjából helyes elkülöníteni a jót a rossztól. A gyakorlatban azonban ez nehezen megvalósítható, mert nem mindenki ugyanazt a mércét tartja irányadónak." 33 E témát vizsgálva Hautzinger a következőképpen fogalmaz: „Az azonosság viszonylagossága az egyediség és a különbözőség relativitását jelenti, miszerint az azonosság nem időtálló tényező, hanem csak adott időszakra és egyes sajátosságok vonatkozásában áll fenn." ${ }^{34} \mathrm{Az}$ azonos mérce keresésében jó megoldás lehet a legkisebb közös többszörös meghatározása, amely a különböző egyéni mércék egységesítését segítheti. Az igazságosság és az adóztatási igazságosság területén találhatunk olyan elfogadott mércét, amely irányíthatja a gondolkodásunkat. Ez a mérce lehet a közösség érdeke, a közjó, amely minden kormányzat cselekvési rendszerének középpontjában kell hogy álljon. „Ha a jó élet eszméje áll a középpontban, ami egy közösség közös élet gyakorlatában van megalapozva: abban a közös jóban, amire ez a gyakorlat irányul, és ami nem neked vagy nekem, hanem a minket magában foglaló közösség számára, s számunkra mint e közösség tagjai számára jó" - írja Tallár Ferenc. ${ }^{35} \mathrm{~A}$ közjónak tehát az lehet a szerepe, hogy kijelöli az egyéni és közösségi cselekvés céljait és határait. Azok a cselekvések nevezhetők értékesnek, helyesnek és igazságosnak, amelyek a közösség érdekét szolgálják. Ezen idea gyakorlati érvényesülése azonban számos konfliktust eredményezhet a közpénzügyi rendszerben. Itt ugyanis közvetlenül ütközhet az egyén és a közösség rövid és hosszú távú érdeke. Gondoljunk arra, hogy milyen társadalmi konszenzus alakítható ki a munkanélküli segélyről. A munkanélküli abban érdekelt, hogy a közpénzek jelentős részét költsék a hosszú távú és valós megélhetést biztosító segélyekre, úgy, hogy közben arra is gondolnia kell, hogy a segélyezés mértékét nyilvánvalóan korlátozhatja a gazdaság jövedelemtermelö képessége, a feketemunka lehetőségei, a kialakult bérszínvonal és az is, hogy esetleges foglalkoztatásakor ő sem lenne hajlandó túl magas járulék fizetésére. A munkavállalók ezzel szemben abban érdekeltek, hogy a társadalmi szolidaritás ezen járulék keretében viszonylag alacsony elvonás formájában jelenjen meg, de gondolkodásukat befolyásolhatja, hogy számukra is fontos, hogy ha ők kerülnek hasonló helyzetbe, számíthassanak megfelelő és kiszámítható támogatásra. Ezért lenne fontos a társadalmi csoportok közötti együttmüködés és párbeszéd. Ugyanez a kérdés a kormányzat oldaláról úgy jelentkezik, hogy bármifajta nyugdíjbiztosítási rendszer hiányosságait a folyó közkiadások egy részének átcsoportosításával lehet megoldani.

33 Idézi TALLÁR Ferenc: Az igazságosság kisiklása. Rawls igazságosságelmélete és a keresztény hagyomány (a tanulmány az OTKA T 34125 számú kutatási programjának támogatásával készült hosszabb írás első része.) 1.

34 HAUtZinger Zoltán: The present and the future of forensic identification. Jurisprudencija, Teismo Ekspertizis Teorija Ir Praktika, Vilnius, 2005, t. 66(58), 101.

35 TALLÁR: i. m., 1. 
Az igazságosság elvének érvényesítése azt kívánná, hogy keressük meg azt a határpontot, amely még minden fél számára elfogadható. A kormányzat választhat a skandináv típusú, magas elvonáson alapuló, viszonylag széles ellátást biztosító rendszer müködtetése, vagy az angolszász, alacsony elvonáson alapuló, alacsony szolgáltatási szintet nyújtó rendszerek, avagy ezek valamely kombinációja között, de bármelyiket is választja, nem állíthatjuk azt, hogy az egyetlen igazságos rendszer jött létre. Taktikai szempontból könnyebb dolgunk van az abszolút közjó meghatározásához képest az egyén cselekedeteinek megítélésében. Itt ugyanis könnyen megállapíthatjuk, hogy az adóalany, polgár pénzügyi cselekedetei a társadalom számára jók vagy rosszak, hasznosak vagy haszontalanok, inkább segítik vagy inkább sértik a közösség értékeit. A fiktív számlázás, a bevételek eltitkolása, az áfacsalás megítélése egyértelmü, a jog és az erkölcs pontosabban vezérel. Ez a megközelítési mód azonban nem érvényesülhet a közszolgáltatások igénybevételénél, amely pedig az egyén helyzetének megítélésében legalább olyan fontos tényező.

Ha az adórendszerre a formális igazságosság, tehát a fizetőképesség elvének szempontjából tekintünk, akkor az nem jelent mást, mint hogy ugyanazokra az esetekre ugyanaz a szabály vonatkozik. Tehát az azonos helyzetüekkel azonosan, a különbözőekkel különböző módon kell bánnunk. Ez valójában a vertikális és a horizontális egyenlőség elvének a megfogalmazása. Ami azt jelenti az adóztatásban, hogy az azonos jövedelmi helyzetben lévőket azonos módon adóztatják. Ennek az elvnek a gyakorlati érvényesítése nehezen valósítható meg, hiszen ez az elv tartalmilag nem mond semmit arról, hogy milyen csoport- vagy adóbázist képző szempontok alapján mondhatjuk az adóalanyokra, hogy azonos a helyzetük. Még a formális fizetőképesség elve alapján sem tudjuk eldönteni, hogy mikor azonos teljes mértékben két adózó helyzete. Más csoportképző szempontokat kell alkalmazni, ha a jövedelemadót, s mást, ha a vagyonadót vagy ha a fogyasztást terhelő adókat vizsgáljuk.

Gondoljunk arra, hogy minden bevétellel szemben költségek, gyakran adókedvezmények állhatnak. Számos példát találunk az idősek, a tartósan munkanélküliek, a házaspárok adózási szempontból történő kedvezményezésére. Fel kell tennünk azt a kérdést, hogy lehet-e annyira objektív az adórendszer, hogy kimondhassuk: amit két ember ugyanúgy tesz, az adóztatási szempontból azonos. Az igazságosság elve ugyanis azt is megfogalmazza, hogy igazságtalan ugyanúgy bánni a különbözőekkel. A világos különbségtételhez a közös nevezők és különbözőségek pontos meghatározására lenne szükség. Arisztotelész már 2500 évvel ezelőtt foglalkozott az emberek között szükségszerűen meglévő természetes különbségekkel, amit az igazságosság érvényesülésénél tekintetbe kell venni. Nem biztos, hogy ha két ember ugyanazt teszi ugyanakkor, az adózási szempontból ugyanolyan következményekkel jár. Gondoljunk a fogyatékos emberek számára a legtöbb európai országban alkalmazott adókedvezményekre, amelynek eredményeként ugyanakkora bevételnél a fogyatékos személy kevesebb adót köteles fizetni hátrányos helyzete miatt. Ez a megoldás méltányos, és a társadalom nagy része elfogadja ezt az elvet, amely világosan mutatja a különbségtétel szükségességét. Musgrave a horizontális méltányosság érvényesülésének tartja, hogy az azonos jövedelmüek azonos mértékủ adót fizessenek, míg vertikális méltányosságnak azt, hogy a különböző fizetőképességűek különböző adóösszegeket fizessenek, annak érdekében, hogy azonos adóterhelést érzékeljenek. 
Véleménye szerint ez valósítja meg az egyenlő elbánás alapelvét. ${ }^{36}$ Ez elméletileg valóban így van, de ennek az elvnek a gyakorlati érvényesülése jelentős nehézséget okoz.

A magyar Alkotmánybíróság e tárgyra vonatkozó gyakorlatából figyelmet érdemel az a megállapítás, hogy „alkotmányellenességhez nemcsak az vezet, ha adott szabályozási koncepción belül valamely (azonos helyzetben lévő) csoportra - alkotmányos indok nélkül - eltérő szabályozás vonatkozik, hanem hátrányos megkülönböztetés az is, ha az adott szabályozási koncepció alkotmányossági szempontból lényegesen eltérő helyzetben lévő csoportokra azonosan vonatkozik, vagyis e körülményt figyelmen kívül hagyja. Ha az ilyen hátrányokozásnak nem ismerhető fel a tárgyilagos mérlegelés szerint való ésszerü indoka - tehát önkényes -, alkotmányellenesség állapítható meg."37

\section{Záró gondolatok}

Összegzésképpen megfogalmazható, hogy az adóztatás igazságosságának kialakításában döntő szerepet játszik a politika. Az igazságosság általános érvényesülési problémái az adóztatási igazságosság vizsgálatakor is megfigyelhetőek. Tanulmányom zárásaként megfogalmaznék néhány olyan elvet, amely az önkorlátozó hatalom együttmüködésével segíthetné az igazságosabb adórendszer létrejöttét.

Véleményem szerint a rossz, de kiszámítható adórendszer is hatékonyabb és társadalmilag elfogadhatóbb, mint a jobbnak tűnő, de folyamatosan átalakuló, amelyhez nem lehet igazodni. A fő cél a stabil és kiszámítható adókörnyezet kialakítása lenne. Idetartozna a létminimum adómentességének tényleges vizsgálata és az adórendszer kialakításakor annak figyelembevétele. Hasznos lenne az adók számának drasztikus csökkentése, az adók költségvetési éven belüli változtatásának a tilalma és az éven túli változtatások mértékének a korlátozása. Fontos lenne, hogy valóságos társadalmi és szakmai vita után, alaptörvényi szinten fogalmaznánk meg ezeket az alapelveket. Meg kell határozni, hogy mit jelent napjainkban a közteherviselés elve, és milyen szerepet játszhatnak ebben a hazai és a nemzetközi vállalatok! Milyen legyen a vagyonadóztatás, legyen-e minden adónem összehangoltan egykulcsos, és az adóztatás a bevételre, vagy a fogyasztásra, vagy a vagyonra terjedjen-e ki? Milyenek legyenek az adókedvezmények? Mit értünk társadalmi szolidaritáson, és van-e határa a szolidaritásnak? Meg kell világosan fogalmazni, hogy milyen összefüggés van a befizetett adók, járulékok, közterhek és az igénybe vett állami szolgáltatások között! Meg kell határoznunk, hogy kik a modern állami müködés haszonélvezői, és kik a vesztesei! Ezeknek a kérdéseknek a megválaszolásához valós társadalmi vita kell, amelybe be kell vonni a létező jogi intézményrendszereket, az Alkotmánybíróságot, az egyetemeket stb.

36 Musgrave-Musgrave: i. m., 33.

37 6/1997. (II. 7.) AB-határozat, ABH 1997, 67. Idézi KLıcsu László: Fenntartható társadalom - egykulcsos adó, Pénzügyi Szemle, 2008 (53. évf.), 4. sz., 710. 
Az adózás igazságosságával kapcsolatos társadalmi és szakmai viták csak nagyon ritkán lángolnak fel, aminek egyik oka, hogy a jogalkotók a modern jogrendszerek kialakulásakor magukhoz ragadták az akkori polgárok felhatalmazása alapján ezeknek a döntéseknek a meghozatalát. Jogi alapelvek és alkotmányos értékek helyett azóta is a kendőzetlen fiskális érdekek dominálnak. Óriási lépés volt kétszáz éve eljutni a közteherviselési kötelezettség elvéhez, de az eltelt idő sem volt elegendő arra, hogy az igazságosság elveit világosan és könnyen alkalmazható módon fogalmazzuk meg. Elemezve a fennálló adórendszereket, adókedvezményeket, államháztartási elosztórendszereket, megállapíthatjuk, hogy a közpénzügyi rendszerek az adott állam politikai, gazdasági és egyéb jellegzetességeit tükrözik. Tanulmányomban arra törekedtem, hogy az igazságosság adóztatásban megjelenő elvi és gyakorlati lehetőségeit mutassam be a jogelmélet és az adójog eszközeivel. E munkámban nem foglalkozhattam olyan fontos kérdésekkel, mint az egykulcsos adó, a vagyonadóztatás vagy a szektorális különadók. Úgy gondolom, hogy ez a megközelítésmód kiemeli az elemzésemet a napi gazdaságpolitika jelenlegi kontextusából és arra törekszik, hogy általánosan érvényes gondolatokat, tapasztalatokat fogalmazzon meg.

\footnotetext{
Abstract

Studying the fairness of taxation is not separable from the general emergence of the social fairness, but some features of its own could be determined. In this paper I examined the problem of the fairness of taxation and drew up the details of the optimal tax system. One single chapter was devoted to the analysis of the relation between the notion of fairness and equity and another was devoted to the analysis of the question of sameness, which is necessary for the understanding of the fairness of taxation.
} 